\title{
Prevalence of Helicobacter pylori vacA, cagA and iceA genotypes and correlation with clinical outcome
}

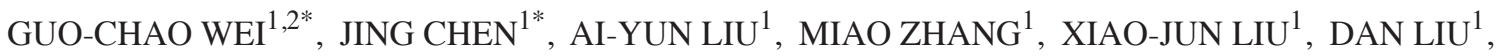 \\ JUN XU ${ }^{1}$, BING-RONG LIU ${ }^{1}$, HONG LING ${ }^{2}$, HUA-XING WU ${ }^{3}$ and YA-JU DU ${ }^{1}$ \\ ${ }^{1}$ Department of Gastroenterology, The Second Affiliated Hospital of Harbin Medical University; \\ ${ }^{2}$ Department of Microbiology, Harbin Medical University; ${ }^{3}$ Department of Endoscopic Center, \\ The Third Affiliated Hospital of Harbin Medical University, Harbin, Heilongjiang 150086, P.R. China
}

Received June 2, 2012; Accepted August 28, 2012

DOI: $10.3892 /$ etm.2012.704

\begin{abstract}
The aim of this study was to assess the genetic status of $\operatorname{cag} A, v a c A$ subtype and iceA genotypes of Helicobacter pylori and the relationship with upper gastrointestinal diseases in Northeast China. Gastric biopsies were obtained from 378 patients with upper gastrointestinal diseases and 197 samples were used. The $\operatorname{cag} A, v a c A$ alleles and ice $A$ genotypes were determined by polymerase chain reaction. $\operatorname{Cag} A$ was present in $176(89.3 \%)$ of 197 patients. Of the 197 cases, $186(94.4 \%)$ had vacA signal sequence s1c allele, $6(3 \%)$ had s1a and 5 (2.5\%) had s1b. The vacA s2 genotype was not detected in our study. VacA middle region sequences, $\mathrm{m} 1$ and $\mathrm{m} 2$, were found in $20(10.2 \%)$ and $150(76.1 \%)$, respectively. The allelic variant iceA1 (70.1\%) was more prevalent than iceA2 (23.4\%). The vacA allele slam2 had a significant relationship with the presence of gastric cancer $(\mathrm{p}<0.05)$ and the ice $A 1$ genotype was also associated with gastric cancer $(p<0.05)$. These may be useful risk factors for upper gastrointestinal diseases.
\end{abstract}

\section{Introduction}

Helicobacter pylori (H. pylori) is a gram-negative microaerophilic bacterium which is one of the most common pathogens in humans and has a worldwide distribution. It is associated with the development of chronic gastritis, peptic ulcer and even gastric cancer (1). On the basis of abundant epidemiological research, H. pylori was classified as a class I carcinogen in humans by the World Health Organization International Agency for Research on Cancer (2).

Correspondence to: Dr Ya-Ju Du, Department of Gastroenterology, The Second Affiliated Hospital of Harbin Medical University, 246 Xuefu Road, Nangang, Harbin, Heilongjiang 150086, P.R. China E-mail: duyaju0451@sina.com

*Contributed equally

Key words: Helicobacter pylori, prevalence, genotype, Northeast China
Several $H$. pylori virulence genes that may be associated with the risk of developing diseases have been identified. The $\operatorname{cag} A$ is a marker of genomic pathogenicity island (cagPAI) encoding the gene product which causes upregulation of interleukin-8 (IL-8) (3). It is considered that $H$. pylori strains possessing $\operatorname{cag} A$ are related to a more severe clinical outcome such as atrophic gastritis or gastric cancer $(4,5)$. The vacA exists in all $H$. pylori strains and encodes vacuolating cell toxins which cause vacuole degeneration of epithelial cells. It includes two different parts: the signal (s) region encoding the signal peptide and the middle $(\mathrm{m})$ region. The s-region is situated at the 5' end of the gene and exists as s1 and s2 alleles. The s1 exists as an s1a, s1b and s1c. The m-region occurs as $\mathrm{m} 1$ or $\mathrm{m} 2$ alleles (6). The mosaic combination of $\mathrm{s}$ - and $\mathrm{m}$-region allelic types produces cytotoxin and is associated with the pathogenicity of the bacterium. In general, type s1m1 and s1m2 strains produce high and moderate levels of toxin, respectively, whereas $\mathrm{s} 2 \mathrm{~m} 2$ strains produce little or no toxin. (7). VacA m1 strains are associated with greater gastric epithelial damage than $\mathrm{m} 2$ strains (8). Another virulence gene designated ice $A$ has two main allelic variants $i c e A 1$ and ice $A 2$ but the function of these variants is unknown. IceAl is upregulated upon contact of $H$. pylori with the gastric epithelium and has been considered as a marker for peptic ulcer disease (9).

In Northeast China, there are no data regarding the pattern of $H$. pylori genotypes in patients. This study aimed to investigate the prevalence of the vacA, cagA and ice $A$ genotypes of $H$. pylori from patients with upper gastrointestinal diseases and the relationship with clinical outcome in Northeast China.

\section{Materials and methods}

Study subjects. We evaluated 378 patients with upper gastrointestinal diseases referred for endoscopy at the Second Affiliated Hospital of Harbin Medical University in 2007 and 2008. Gastric mucosal biopsy specimens were obtained from each patient: one for pathological diagnosis, another for histological detection of $H$. pylori and the last for genomic DNA extraction and polymerase chain reaction (PCR).

The study was approved by the Ethics Committee of Harbin Medical University. Written informed consent was obtained from each patient prior to enrolling in the study. 
Table I. Primer sequences for human HP 16S rRNA, cagA, vacA and iceA.

\begin{tabular}{|c|c|c|c|c|}
\hline Gene & Primer & Primer sequence $\left(5^{\prime} \rightarrow 3^{\prime}\right)^{\mathrm{a}}$ & Product size (bp) & Reference \\
\hline 16S rRNA & $\begin{array}{l}\text { cp-1 } \\
\text { cp-2 }\end{array}$ & $\begin{array}{l}\text { GCGCAATCAGCGTCAGGTAATG } \\
\text { GCTAAGAGATCAGCCTATGTCC }\end{array}$ & 500 & (37) \\
\hline $\operatorname{cag} \mathrm{A}$ & $\begin{array}{l}\text { cagA-F } \\
\text { cagA-R }\end{array}$ & $\begin{array}{l}\text { GATAACAGGCAAGCTTTTGAGG } \\
\text { CTGCAAAAGATTGTTTGGCAGA }\end{array}$ & 349 & (18) \\
\hline s1a & $\begin{array}{l}\text { S1a-F } \\
\text { VA1-R }\end{array}$ & $\begin{array}{l}\text { TCTYGCTTTAGTAGGAGC } \\
\text { CTGCTTGAATGCGCCAAAC }\end{array}$ & 212 & (18) \\
\hline $\mathrm{s} 1 \mathrm{~b}$ & $\begin{array}{l}\text { SS3-R } \\
\text { VA1-R }\end{array}$ & $\begin{array}{l}\text { AGCGCCATACCGCAAGAG } \\
\text { CTGCTTGAATGCGCCAAAC }\end{array}$ & 187 & (18) \\
\hline s1c & $\begin{array}{l}\text { S1c-F } \\
\text { VA1-R }\end{array}$ & $\begin{array}{l}\text { CTYGCTTTAGTRGGGYTA } \\
\text { CTGCTTGAATGCGCCAAAC }\end{array}$ & 213 & (18) \\
\hline s2 & $\begin{array}{l}\text { SS2-F } \\
\text { VA1-R }\end{array}$ & $\begin{array}{l}\text { GCTAACACGCCAAATGATCC } \\
\text { CTGCTTGAATGCGCCAAAC }\end{array}$ & 199 & (8) \\
\hline $\mathrm{m} 1$ & $\begin{array}{l}\text { VA3-F } \\
\text { VA3-R }\end{array}$ & $\begin{array}{l}\text { GGTCAAAATGCGGTCATGG } \\
\text { CCATTGGTACCTGTAGAAAC }\end{array}$ & 290 & (38) \\
\hline $\mathrm{m} 2$ & $\begin{array}{l}\text { VA4-F } \\
\text { VA4-R }\end{array}$ & $\begin{array}{l}\text { GGAGCCCCAGGAAACATTG } \\
\text { CATAACTAGCGCCTTGCAC }\end{array}$ & 352 & (38) \\
\hline iceA1 & $\begin{array}{l}\text { iceA1-F } \\
\text { iceA1-R }\end{array}$ & $\begin{array}{l}\text { GTGTTTTTAACCAAAGTATC } \\
\text { CTATAGCCASTYTCTTTGCA }\end{array}$ & 247 & (35) \\
\hline iceA2 & $\begin{array}{l}\text { iceA2-F } \\
\text { iceA2-R }\end{array}$ & $\begin{array}{l}\text { GTTGGGTATATCACAATTTAT } \\
\text { TTRCCCTATTTTCTAGTAGGT }\end{array}$ & $229 / 334$ & (35) \\
\hline
\end{tabular}

${ }^{\mathrm{a}} \mathrm{Y}$ is $\mathrm{C}$ or $\mathrm{T}, \mathrm{R}$ is $\mathrm{A}$ or $\mathrm{G}$ and $\mathrm{S}$ is $\mathrm{C}$ or $\mathrm{G}$.

Histological assessment. The biopsy samples were fixated in $10 \%$ formalin, then sliced into 4- to 6-mm pieces, dehydrated in ethanol, embedded in paraffin wax, sectioned (5- $\mu \mathrm{m}$ thick), and stained with hematoxylin and eosin (H\&E). The presence of $H$. pylori in the sections was determined using a modified Gram staining protocol and taking into consideration its morphological characteristics which included a curved and spiral form and intense purple coloring (10). Pathological diagnoses were evaluated in a blinded manner by two independent pathologists and were defined as gastritis (active chronic gastritis or closed-type atrophic gastritis), gastric ulcer and gastric cancer.

Genomic DNA extraction. DNA was extracted from the biopsy specimens using the Genomic DNA purification system (Promega, USA) according to the manufacturer's instructions and stored at $-20^{\circ} \mathrm{C}$ until analysis.

Diagnosis of H. pylori infection. H. pylori-positive status was defined as positive histology and positive 16S-rRNA PCR. A 500-bp region of 16S-rRNA was amplified by PCR using primers CP-1/CP-2 (Table I). Five microlitres of DNA was added to $50 \mu 1$ of reaction mixture containing $1 \mathrm{X}$ PCR buffer, $0.2 \mathrm{mM}$ dNTPs and $0.3 \mu \mathrm{M}$ primers as well as $1.25 \mathrm{U}$ Taq polymerase (Takara Bio, Inc., Japan). The incubation conditions were as follows: a 5 -min preincubation at $95^{\circ} \mathrm{C}$, followed by
30 cycles of $1 \mathrm{~min}$ at $94^{\circ} \mathrm{C}, 1 \mathrm{~min}$ at $58^{\circ} \mathrm{C}, 1 \mathrm{~min}$ at $72^{\circ} \mathrm{C}$, and a final 5-min incubation at $72^{\circ} \mathrm{C}$. Positive results were indicative of a diagnosis of $H$. pylori infection.

Genotyping of H. pylori. The systems of PCR were the same as mentioned above except for the primers. The amplification cycles consisted of an initial denaturation at $94^{\circ} \mathrm{C}$ for $5 \mathrm{~min}$ and then denaturation at $94^{\circ} \mathrm{C}$ for $30 \mathrm{sec}$, primer annealing at $60,56,58$ and $48^{\circ} \mathrm{C}$ for $\operatorname{cag} A, \operatorname{vac} A$ (s1a, s1b, s1c and s2), vacA $(\mathrm{m} 1, \mathrm{~m} 2)$ and ice $A$, respectively, for one-half minute and extension at $72^{\circ} \mathrm{C}$ for $45 \mathrm{sec}$. All reactions were performed through 35 cycles. The final cycle included an extension step for $5 \mathrm{~min}$. Primers used for genotyping $\operatorname{cag} A, v a c A$ and ice $A$ genes are listed in Table I. PCR products were analyzed on $1.5 \%$ agarose gel electrophoresis with ethidium bromide. Images were quantified via the Gene Genius system (Syngene, England, UK). For strains that were cagA-negative as determined by PCR, Southern blotting was performed according to the method described by Pan et al (11).

Statistical analyses. Statistical tests were performed with SPSS software version 11.5 (SPSS Inc., Chicago, IL, USA). A Chi-square test and Fisher's exact test were used to assess the association amongst the genotypes and between specific genotypes and upper gastrointestinal diseases. P-values $<0.05$ were considered to indicate a statistically significant result. 
Table II. Distribution of 197 patients with different clinical outcomes, according to age and gender.

\begin{tabular}{|c|c|c|c|c|}
\hline \multirow[b]{2}{*}{ Classification } & \multicolumn{3}{|c|}{ Clinical status } & \multirow[b]{2}{*}{$\begin{array}{c}\text { Total } \\
\mathrm{n}=197(\%)\end{array}$} \\
\hline & $\begin{array}{c}\mathrm{GU}^{\mathrm{a}} \\
\mathrm{n}=86(\%)\end{array}$ & $\begin{array}{c}\mathrm{GS}^{\mathrm{b}} \\
\mathrm{n}=58(\%)\end{array}$ & $\begin{array}{c}\mathrm{GC}^{\mathrm{c}} \\
\mathrm{n}=53(\%)\end{array}$ & \\
\hline \multicolumn{5}{|l|}{ Age (years) } \\
\hline $21-30$ & $7(8.1)$ & $2(3.5)$ & $0(0.0)$ & $9(4.6)$ \\
\hline $31-40$ & $12(14.0)$ & $11(19.0)$ & $4 \quad(7.5)$ & $27(13.7)$ \\
\hline $41-50$ & $33(38.4)$ & $17(29.3)$ & $17(32.1)$ & $67(34.0)$ \\
\hline $51-60$ & $24(27.9)$ & $17(29.3)$ & $16(30.2)$ & $57(29.0)$ \\
\hline$>60$ & $10(11.6)$ & $11(18.9)$ & $16(30.2)$ & 37 (18.7) \\
\hline \multicolumn{5}{|l|}{ Gender } \\
\hline Male (M) & $52(60.5)$ & $37(63.8)$ & $34(64.2)$ & $123(62.4)$ \\
\hline Female (F) & $34(39.5)$ & $21(36.2)$ & $19(35.8)$ & 74 (37.6) \\
\hline $\mathrm{M}: \mathrm{F}$ & $1: 0.7$ & $1: 0.6$ & $1: 0.6$ & $1: 0.6$ \\
\hline
\end{tabular}

${ }^{\mathrm{a}}$ Gastric ulcer; ${ }^{\mathrm{b}}$ gastritis; ${ }^{\mathrm{c} g a s t r i c}$ cancer.

Table III. Association of $v a c A$ with $\operatorname{cag} A$ and iceA genotypes.

\begin{tabular}{|c|c|c|c|c|c|}
\hline vacA & $\operatorname{cag} \mathrm{A}^{+} \mathrm{n}(\%)$ & $\operatorname{cag} \mathrm{A}^{-} \mathrm{n}(\%)$ & iceA1 n (\%) & iceA2 n (\%) & iceA1/iceA2 n (\%) \\
\hline \multicolumn{6}{|l|}{ s-region } \\
\hline s1a & $4(66.7)$ & $2(33.3)$ & $5 \quad(83.3)$ & $1(16.7)$ & $0(0.0)$ \\
\hline $\mathrm{s} 1 \mathrm{~b}$ & $3(60.0)$ & $2(40.0)$ & $5(100.0)$ & $\begin{array}{ll}0 & (0.0)\end{array}$ & $0(0.0)$ \\
\hline s1c & 169 (90.9) & $17(9.1)$ & 128 (68.8) & $45(24.2)$ & $13(7.0)$ \\
\hline \multicolumn{6}{|l|}{ m-region } \\
\hline $\mathrm{m} 1$ & $18(90.0)$ & $2(10.0)$ & $14(70.0)$ & $6(30.0)$ & $0(0.0)$ \\
\hline $\mathrm{m} 2$ & $139(93.0)$ & $11(7.0)$ & $110(73.4)$ & $38(25.3)$ & $2(1.3)$ \\
\hline $\mathrm{m} 1 \mathrm{~m} 2$ & $19(84.0)$ & $8(16.0)$ & $14(70.4)$ & $2(22.2)$ & $11(7.4)$ \\
\hline \multicolumn{6}{|l|}{$\mathrm{s} / \mathrm{m}$ region } \\
\hline s1am2 & $4(66.7)$ & $2(33.3)$ & $5 \quad(83.3)$ & $1(16.7)$ & $\begin{array}{ll}0 & (0.0)\end{array}$ \\
\hline $\mathrm{s} 1 \mathrm{bm} 2$ & $3(60.0)$ & $2(40.0)$ & $5(100.0)$ & $0 \quad(0.0)$ & $0 \quad(0.0)$ \\
\hline $\mathrm{s} 1 \mathrm{~cm} 1$ & $18(90.0)$ & $2(10.0)$ & $14(70.0)$ & $6(30.0)$ & $0 \quad(0.0)$ \\
\hline $\mathrm{s} 1 \mathrm{~cm} 2$ & $132(95.0)$ & $7 \quad(5.0)$ & $100 \quad(71.9)$ & 37 (26.6) & $2(1.5)$ \\
\hline $\mathrm{s} 1 \mathrm{~cm} 1 \mathrm{~m} 2$ & $19(70.4)$ & $8(29.6)$ & $14 \quad(51.9)$ & $2(7.4)$ & $11(40.7)$ \\
\hline
\end{tabular}

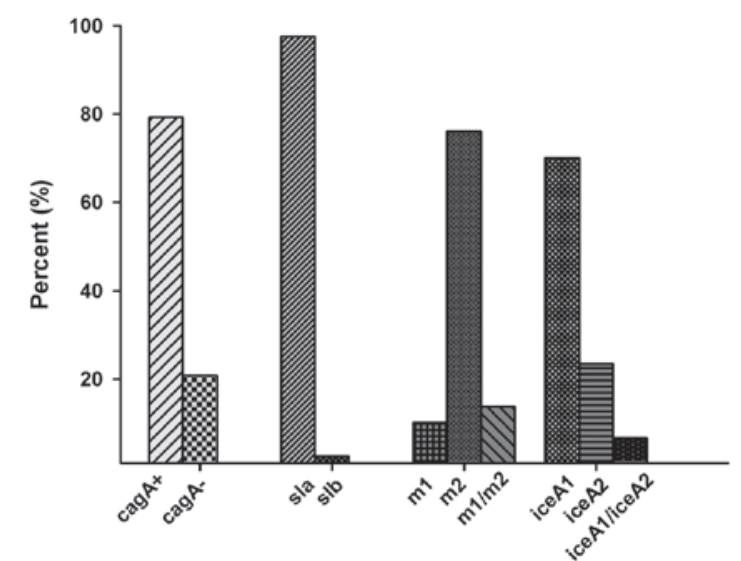

Figure 1.Distribution of $c a g A, v a c A$ and $i c e A$ alleles of $H$.pylori from 197 patients with upper gastrointestinal diseases. M1m2, multiple vacA genotypes with $\mathrm{m} 1$ and $\mathrm{m} 2$. IceA1/iceA2, mixed iceA genotypes with iceA1 and iceA2.

\section{Results}

DNA was successfully extracted from 378 gastric mucosa tissues of patients with gastrointestinal diseases and 197 were confirmed as $H$. pylori infection-positive by histology and PCR amplification. H. pylori-infected patients were evaluated for the relationship of age and gender with disease as shown in Table II.

Detection of $H$. pylori genotypes. Overall, the presence of the $\operatorname{cagA}$ gene was detected in 176 cases (89.3\%). A negative status for the other $21(10.7 \%)$ cases was confirmed by Southern blotting, and the results were negative as before. All of the samples were positive for vacA (both the s-region and the m-region). Of the 197 cases, $186(94.4 \%)$ had vacA signal sequence s1c allele, $6(3 \%)$ had s1a and $5(2.5 \%)$ had s1b. The vacA s2 genotype was 
Table IV.vacA, cagA and iceA status of $H$. pylori from 197 patients.

\begin{tabular}{|c|c|c|c|c|}
\hline \multirow[b]{2}{*}{ Genotype status } & \multicolumn{3}{|c|}{ Clinical status } & \multirow[b]{2}{*}{ Total $\mathrm{n}=197(\%)$} \\
\hline & $\mathrm{GU}^{\mathrm{a}} \mathrm{n}=86(\%)$ & $\mathrm{GS}^{\mathrm{b}} \mathrm{n}=58(\%)$ & $\mathrm{GC}^{\mathrm{c}} \mathrm{n}=53(\%)$ & \\
\hline \multicolumn{5}{|l|}{$\operatorname{vacA}$} \\
\hline s1am2 & $4 \quad(4.6)$ & $2 \quad(3.4)$ & $\begin{array}{ll}0 & (0.0)\end{array}$ & $6 \quad(3.0)$ \\
\hline $\mathrm{s} 1 \mathrm{bm} 2$ & $\begin{array}{ll}0 & (0.0)\end{array}$ & $0 \quad(0.0)$ & $5 \quad(9.4)$ & $5 \quad(2.5)$ \\
\hline $\mathrm{s} 1 \mathrm{~cm} 1$ & $16(18.6)$ & $4 \quad(6.9)$ & $0 \quad(0.0)$ & $20(10.2)$ \\
\hline $\mathrm{s} 1 \mathrm{~cm} 2$ & $51(59.4)$ & $43(74.2)$ & $45(84.9)^{\mathrm{d}}$ & 139 (70.6) \\
\hline $\mathrm{s} 1 \mathrm{~cm} 1 \mathrm{~m} 2$ & $15(17.4)$ & $9(15.5)$ & $3(5.7)$ & $27(13.7)$ \\
\hline \multicolumn{5}{|l|}{$\operatorname{cag} \mathrm{A}$} \\
\hline $\operatorname{cag} \mathrm{A}^{+}$ & $78(90.7)$ & $53(91.4)$ & $45(84.9)$ & $176(89.3)$ \\
\hline $\operatorname{cag} \mathrm{A}^{-}$ & $8(9.3)$ & $5 \quad(8.6)$ & $8(15.1)$ & $21(10.7)$ \\
\hline \multicolumn{5}{|l|}{ iceA } \\
\hline iceA1 & $63(73.3)$ & $34(58.6)$ & $41(77.4)^{\mathrm{d}}$ & $138(70.0)$ \\
\hline iceA2 & $14(16.3)$ & $21(36.2)$ & $11(20.8)$ & $46(23.4)$ \\
\hline iceA1/iceA2 & $9(10.4)$ & $3 \quad(5.2)$ & $1 \quad(1.9)$ & 13 (6.6) \\
\hline
\end{tabular}

${ }^{\mathrm{a}}$ Gastric ulcer; ${ }^{\mathrm{b}}$ gastritis; ${ }^{\mathrm{c}}$ gastric cancer. ${ }^{\mathrm{d}} \mathrm{P}<0.05$.

Table V. Combined vacA, $\operatorname{cag} A$, iceA genotypes.

Clinical status

\begin{tabular}{|c|c|c|c|c|}
\hline \multirow[b]{2}{*}{ Combination } & & \multirow[b]{2}{*}{ Total n (\%) } \\
\hline & $\mathrm{GU}^{\mathrm{a}} \mathrm{n}(\%)$ & $\mathrm{GS}^{\mathrm{b}} \mathrm{n}(\%)$ & $\mathrm{GC}^{\mathrm{c}} \mathrm{n}(\%)$ & \\
\hline s1am2/cagA A $^{+}$iceA1 & 1 (1.5) & $2(4.1)$ & $0 \quad(0.0)$ & $3(1.8)$ \\
\hline s1am2/cagA-/iceA1 & $2(2.9)$ & $0 \quad(0.0)$ & $0 \quad(0.0)$ & $2(1.2)$ \\
\hline s 1 am $2 /$ cag $A^{+} /$iceA 2 & $1 \quad(1.5)$ & $0 \quad(0.0)$ & $0 \quad(0.0)$ & $1 \quad(0.6)$ \\
\hline s1bm2/cagA+/iceA1 & $0 \quad(0.0)$ & $0 \quad(0.0)$ & $3(6.0)$ & $3(1.8)$ \\
\hline s1bm2/cagA-/iceA1 & $0 \quad(0.0)$ & $0 \quad(0.0)$ & $2(4.0)$ & $2(1.2)$ \\
\hline $\mathrm{s} 1 \mathrm{~cm} 1 / \mathrm{cag}^{+} /$iceA 1 & $10(14.3)$ & $2(4.1)$ & $0 \quad(0.0)$ & $12(7.1)$ \\
\hline s1cm1/cagA-/iceA1 & $2(2.9)$ & $0 \quad(0.0)$ & $0 \quad(0.0)$ & $2(1.2)$ \\
\hline $\mathrm{s} 1 \mathrm{~cm} 1 / \mathrm{cag} \mathrm{A}^{+} /$iceA 2 & $4 \quad(5.8)$ & $2(4.1)$ & $0 \quad(0.0)$ & $6 \quad(3.6)$ \\
\hline s1cm2/cagA $A^{+}$iceA1 & $40(58.0)$ & $23(47.0)$ & $32(64.0)$ & $95(56.5)$ \\
\hline s1cm2/cagA-/iceA1 & $2(2.9)$ & $1 \quad(2.0)$ & $2(4.0)$ & $5 \quad(3.0)$ \\
\hline s $1 \mathrm{~cm} 2 / \mathrm{cagA}^{+} /$iceA2 & $6(8.7)$ & $18(36.7)$ & $11(22.0)$ & $35(20.8)$ \\
\hline s1cm2/cagA-/iceA2 & $1 \quad(1.5)$ & $1 \quad(2.0)$ & $0 \quad(0.0)$ & $2(1.2)$ \\
\hline Total & $69(100)$ & $49(100)$ & $50(100)$ & $168(100)$ \\
\hline
\end{tabular}

${ }^{\mathrm{a}}$ gastric ulcer; ${ }^{\mathrm{b}}$ gastritis; ${ }^{\mathrm{c} g a s t r i c}$ cancer. Twenty-nine patients with mixed infection were excluded.

not detected in our study. In the m-region, 27 cases contained both $\mathrm{m} 1$ and $\mathrm{m} 2$. In these cases the $\mathrm{m} 1$ allele was found in 20 $(10.2 \%)$ isolates and $\mathrm{m} 2(76.1 \%)$ in 150 cases, which indicating the presence of mixed infection. The vacA slam 2 genotype was identified in $6(3.0 \%)$ participants, the vacA s1bm2 was identified in 5 (2.5\%) participants, $\mathrm{s} 1 \mathrm{~cm} 1$ was identified in 20 participants, and $\mathrm{s} 1 \mathrm{~cm} 2$ gene was identified in 139 ones. IceAl was found in 138 (70.1\%) and iceA2 was detected in 46 (23.4\%) cases. The iceA2 amplification yielded both the 229and 334-bp bands due to the presence of a 105-bp in-frame amplicon present in the 334-bp band that was absent in the 229-bp band. Mixed iceA (iceA1 + iceA2) genotypes were found in $13(6.7 \%)$ of our isolates (Fig. 1).

Association among the genotypes. CagA was present in 124 out of 138 iceAl cases $(91.1 \%)$ and 44 out of 46 ice $A 2$ cases $(95.5 \%)(\mathrm{p}>0.05)$ where 29 patients with mixed infection were excluded. Due to the lack of $v a c A$ s2, we could not analyse the association between $\operatorname{cag} A$ status and vacA genotypes and between ice $A$ and $v a c A$ genotypes (Table III). 
Relationship between genotypes and gastric diseases. Of the 197 strains studied, 86 were diagnosed with gastric ulcer, 58 with gastritis and 53 with gastric cancer. VacA s1cm 2 was detected in all the disease conditions, and it was more significantly associated with the presence of gastric cancer $(\mathrm{p}<0.05)$. S1am2 and s1cm1 were detected in all the disease except gastric cancer, while s1bm2 was found in gastric cancer alone (Table IV). Surprisingly, iceAl had a statistically significant association with gastric cancer $(\mathrm{p}<0.05)$. Neither cagA nor ice $A 2$ was associated with various diseases. The most prevalent combination $\mathrm{cagA} / \mathrm{s} 1 \mathrm{~cm} 2 /$ ice $A 1$ was present in $56.6 \%$ (95 of 168) including $58.0 \%$ (40 of 69) of gastric ulcer, $47.0 \%$ (23 of 49) of gastritis and $64.0 \%$ (32 of 50) of gastric cancer (Table V). However, no significant association was found between the combination genotypes and diseases ( $p>0.05)$.

\section{Discussion}

This study was designed to characterize the genotype of H. pylori from gastric biopsy specimens from patients with upper gastrointestinal diseases and the relationship with clinical outcome in Northeast China. H. pylori was analysed for the presence of the genes for $c a g A, v a c A$ and iceA. To our knowledge, this was the first study to analyse the different proposed virulence genes characterized in $H$. pylori and the relationship between the genes and upper gastrointestinal diseases in Northeast China.

CagA gene, as a major $H$. pylori virulence factor, was reported to be strongly associated with atrophic gastritis and gastric cancer as previously described. This is probably the main cause of a high incidence of gastric cancer in the region

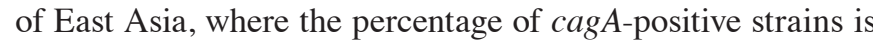
above $90 \%$ (12). Worldwide, the presence of the cagA gene varies from $50 \%$ in some Middle Eastern countries to $99 \%$ in East Asian countries (13-15). In this study, $\operatorname{cag} A$ was found in $89.3 \%$ of $H$. pylori-infected patients. The result is similar to data reported from other districts of China $(11,16)$. However, we did not find an association between $\operatorname{cag} A$ and clinical results. Notably, of the 29 mixed infection cases, 8 had cagAnegative and strains with an absence of $\operatorname{cag} A$ appeared to be associated with mixed infection $(\mathrm{p}=0.004)$.

The present study demonstrated that all strains of $H$. pylori carried the vacA s1 allele. Previous studies noted that s1c was present exclusively in isolates from East Asia (16-18). Our report also demonstrated a high prevalence of type slc strains in this region, up to $94.4 \%$. The result was similar to the report of Wang et al (19) and slightly higher than the prevalence in Beijing and Shanghai, which may result from the fact that more foreigners from America and Europe live in the two cities above, as either the sla or slb subtype was present in almost all strains in Central and South America, and in the majority of strains in Spain and Portugal $(20,21)$, nevertheless rarely in East Asia $(12,16)$. The vacA s2 genotype was prominently prevalent in Africa (9), and consistent to the outcome reported from China and Korea, s2 failed to be detected in this study $(19,22)$.

Worldwide prevalence of vacA strains varies geographically. S1m1 strains were predominant in Japan and Korea $(18,23)$ while s1m2 was found in Turkey and Northern and Eastern Europe $(20,24)$. In Alaskans, H. pylori had either the vacA s1m1 (44.6\%) or $\mathrm{s} 2 \mathrm{~m} 2$ (38.3\%) (15). In China, prevalence of strains documented a greatly distinct pattern, with s $1 \mathrm{~m} 1$ and $\mathrm{s} 1 \mathrm{~m} 2$ sharing the same proportion in the Province of Xi'an (25) and s1m2 strains in Beijing, Taiwan and Hong Kong $(16,19,26)$. The latter condition was similar to our study.

Generally, s1m2 forms of vacA bind to and vacuolate a narrower range of cells than $\mathrm{s} 1 \mathrm{~m} 1$ forms and induce less damage, yet they also act as efficient membrane pores and increase paracellular (27) permeability. The alleles of s1m1 and $\mathrm{s} 1 \mathrm{~m} 2$ encode to produce toxin which are common in patients with gastrosis (27). In Latin America and Germany, s1m1 was found to have a high correlation with gastric ulcer and gastric carcinoma $(21,28)$. The strains of $v a c A \mathrm{~s} 2 \mathrm{~m} 1$ and $\mathrm{s} 2 \mathrm{~m} 2$ engender low toxic toxin which rarely correlates with gastric ulcer and gastric carcinoma (29). In our study, the vacA gene encoding the $\mathrm{s} 1 \mathrm{~cm} 2$ was associated with gastic cancer. Therefore, the s-region should be responsible for gastrosis other than the m-region.

Another virulent factor is the ice $A$ gene, with two allelic variants ice $A 1$ and ice $A 2$ having been identified. The prevalence of the iceAl genotype is $70.1 \%$ in this study, basically consistent with data reported from China, Thailand, Korea and Tunisia $(9,23,30,31)$. Meanwhile, iceA2 is predominant in Brazil, the US, Europe and South Africa $(6,18,32,33)$. It was demonstrated that iceAl was significantly associated with peptic ulcer disease in Holland (34) and the US (35). However, studies from other countries such as in Korea, Colombia and India could not confirm the result $(18,36)$. Some researchers found that the iceA2 genotype was most frequently found in patients with duodenal ulcer or gastric carcinoma $(18,36)$. However, it is difficult to admit that iceA2, a gene that is considered as a protective factor in some regions and that is associated with more severe diseases in other places, could be considered a molecular marker of more virulent $H$. pylori strains (33). It was well worth mentioning that the iceAl strains, based on this study, have a significant association with gastric cancer.

In common with other studies, there exists a strong indication that the presence of multiple $H$. pylori strains are detectable in clinical samples. Some studies have claimed multiple genotypes have a link with duodenal ulcers (9). It may be speculated that multiple strains contribute to increasing the potential chances of infecting pathogen. By colonizing a variety of receptors expressed on gastric epithelial cells, m1 and $\mathrm{m} 2$ strains probably tend to bring about pathological changes. Multi-colonization arising from the co-existence of more than one strain exert burden to patients under eradication treatment and furthermore dramatically enhance the risk of malignant tumors of the digestive tract among adult patients. However, our data did not indicate that multiple strain infection increases the risk of developing diseases ( $p>0.05)$.

In conclusion, the present study identified the prevalence of main virulence factor genes $\operatorname{cag} A, \mathrm{~s} 1 \mathrm{~cm} 2$ and ice $A 1$ in Northeast China. The vacA gene encoding $\mathrm{s} 1 \mathrm{~cm} 2$ was found to predominate in gastic cancer patients, and the iceAl genotype was also associated with gastric cancer. It may be insufficient to analyse gastrointestinal diseases simply by genotyping H. pylori, and therefore, we must evaluate the pathogenesis of diseases by a combination of the analysis of bacterial factors, genetic factors of the host and environmental factors. 


\section{Acknowledgements}

This study was supported by a grant from the Natural Science Foundation of Heilongjiang Province (grant no. D2007-72).

\section{References}

1. Blaser MJ: Ecology of Helicobacter pylori in the human stomach. J Clin Invest 100: 759-762, 1997.

2. Yamazaki S, Yamakawa A, Okuda T, et al: Distinct diversity of $v a c A, c a g A$, and cagE genes of Helicobacter pylori associated with peptic ulcer in Japan. J Clin Microbiol 43: 3906-3916, 2005.

3. Jenks PJ, Megraud F and Labigne A: Clinical outcome after infection with Helicobacter pylori does not appear to be reliably predicted by the presence of any of the genes of the cag pathogenicity island. Gut 43: 752-758, 1998.

4. Huang JQ, Zheng GF, Sumanac K, Irvine EJ and Hunt RH: Meta-analysis of the relationship between $\operatorname{cagA}$ seropositivity and gastric cancer. Gastroenterology 125: 1636-1644, 2003.

5. Rathbone $\mathrm{M}$ and Rathbone B: Helicobacter pylori and gastric cancer. Recent Results Cancer Res 185: 83-97, 2011.

6. Tanih NF, McMillan M, Naidoo N, Ndip LM, Weaver LT and Ndip RN: Prevalence of Helicobacter pylori vacA, cagA and iceA genotypes in South African patients with upper gastrointestinal diseases. Acta Trop 116: 68-73, 2010.

7. Tan HJ, Rizal AM, Rosmadi MY and Goh KL: Distribution of Helicobacter pylori cagA, cagE and vacA in different ethnic groups in Kuala Lumpur, Malaysia. J Gastroenterol Hepatol 20: 589-594, 2005

8. Atherton JC, Cao P, Peek RM Jr, Tummuru MK, Blaser MJ and Cover TL: Mosaicism in vacuolating cytotoxin alleles of Helicobacter pylori. Association of specific vacA types with cytotoxin production and peptic ulceration. J Biol Chem 270 . 17771-17777, 1995.

9. Ben Mansour K, Fendri C, Zribi M, et al: Prevalence of Helicobacter pylori vacA, cagA, ice A and oipA genotypes in Tunisian patients. Ann Clin Microbiol Antimicrob 9: 10, 2010.

10. Assumpcao MB, Martins LC, Melo Barbosa HP, et al: Helicobacter pylori in dental plaque and stomach of patients from Northern Brazil. World J Gastroenterol 16: 3033-3039, 2010.

11. Pan ZJ, van der Hulst RW, Feller M, et al: Equally high prevalences of infection with cagA-positive Helicobacter pylori in Chinese patients with peptic ulcer disease and those with chronic gastritis-associated dyspepsia. J Clin Microbiol 35: 1344-1347, 1997.

12. Maeda S, Ogura K, Yoshida H, et al: Major virulence factors, VacA and CagA, are commonly positive in Helicobacter pylori isolates in Japan. Gut 42: 338-343, 1998.

13. Al Qabandi A, Mustafa AS, Siddique I, Khajah AK, Madda JP and Junaid TA: Distribution of vacA and $\operatorname{cag} A$ genotypes of Helicobacter pylori in Kuwait. Acta Trop 93: 283-288, 2005.

14. Lai CH, Kuo CH, Chen YC, et al: High prevalence of cagA- and babA2-positive Helicobacter pylori clinical isolates in Taiwan. J Clin Microbiol 40: 3860-3862, 2002.

15. Miernyk K, Morris J, Bruden D, et al: Characterization of Helicobacter pylori cagA and vacA genotypes among Alaskans and their correlation with clinical disease. J Clin Microbiol 49: 3114-3121, 2011.

16. Wong BC, Yin Y, Berg DE, et al: Distribution of distinct vacA, cagA and iceA alleles in Helicobacter pylori in Hong Kong. Helicobacter 6: 317-324, 2001.

17. van Doorn LJ, Figueiredo C, Sanna R, et al: Expanding allelic diversity of Helicobacter pylori vacA. J Clin Microbiol 36: $2597-$ 2603, 1998.

18. Yamaoka Y, Kodama T, Gutierrez O, Kim JG, Kashima K and Graham DY: Relationship between Helicobacter pylori iceA, $\operatorname{cag} A$, and $\operatorname{vac} A$ status and clinical outcome: studies in four different countries. J Clin Microbiol 37: 2274-2279, 1999.
19. Wang J, van Doorn LJ, Robinson PA, et al: Regional variation among vacA alleles of Helicobacter pylori in China. J Clin Microbiol 41: 1942-1945, 2003.

20. Van Doorn LJ, Figueiredo C, Megraud F, et al: Geographic distribution of vacA allelic types of Helicobacter pylori. Gastroenterology 116: 823-830, 1999.

21. Sugimoto $M$ and Yamaoka Y: The association of vacA genotype and Helicobacter pylori-related disease in Latin American and African populations. Clin Microbiol Infect 15: 835-842, 2009.

22. Choe YH, Kim PS, Lee DH, et al: Diverse vacA allelic types of Helicobacter pylori in Korea and clinical correlation. Yonsei Med J 43: 351-356, 2002.

23. Kim SY, Woo CW, Lee YM, et al: Genotyping CagA, VacA subtype, IceA1, and BabA of Helicobacter pylori isolates from Korean patients, and their association with gastroduodenal diseases. J Korean Med Sci 16: 579-584, 2001.

24. Erzin Y, Koksal V, Altun S, et al: Prevalence of Helicobacter pylori vacA, cagA, cagE, ice $A$, babA2 genotypes and correlation with clinical outcome in Turkish patients with dyspepsia. Helicobacter 11: 574-580, 2006.

25. Qiao W, Hu JL, Xiao B, et al: $\operatorname{cag} A$ and vacA genotype of Helicobacter pylori associated with gastric diseases in Xi'an area. World J Gastroenterol 9: 1762-1766, 2003.

26. Perng CL, Lin HJ, Sun IC, Tseng GY and Facg: Helicobacter pylori cagA, iceA and vacA status in Taiwanese patients with peptic ulcer and gastritis. J Gastroenterol Hepatol 18: 1244-1249, 2003.

27. Blaser MJ and Atherton JC: Helicobacter pylori persistence: biology and disease. J Clin Invest 113: 321-333, 2004.

28. Miehlke S, Kirsch C, Agha-Amiri K, et al: The Helicobacter pylori vacA s1, $\mathrm{m} 1$ genotype and $\operatorname{cag} A$ is associated with gastric carcinoma in Germany. Int J Cancer 87: 322-327, 2000.

29. Bindayna KM and Al Mahmeed A: vacA genotypes in Helicobacter pylori strains isolated from patients with and without duodenal ulcer in Bahrain. Indian J Gastroenterol 28: 175-179, 2009.

30. Han YH, Liu WZ, Zhu HY and Xiao SD: Clinical relevance of ice A and babA2 genotypes of Helicobacter pylori in a Shanghai population. Chin J Dig Dis 5: 181-185, 2004.

31. Chomvarin C, Namwat W, Chaicumpar K, et al: Prevalence of Helicobacter pylori vacA, cagA, cagE, ice A and babA 2 genotypes in Thai dyspeptic patients. Int J Infect Dis 12: 30-36, 2008.

32. Podzorski RP, Podzorski DS, Wuerth A and Tolia V: Analysis of the vacA, $\operatorname{cag} A, \operatorname{cagE}$, ice A, and babA2 genes in Helicobacter pylori from sixty-one pediatric patients from the Midwestern United States. Diagn Microbiol Infect Dis 46: 83-88, 2003.

33. Ashour AA, Collares GB, Mendes EN, et al: iceA genotypes of Helicobacter pylori strains isolated from Brazilian children and adults. J Clin Microbiol 39: 1746-1750, 2001.

34. van Doorn LJ, Figueiredo C, Sanna R, et al: Clinical relevance of the $\operatorname{cag} A, v a c A$, and iceA status of Helicobacter pylori. Gastroenterology 115: 58-66, 1998.

35. Peek RM Jr, Thompson SA, Donahue JP, et al: Adherence to gastric epithelial cells induces expression of a Helicobacter pylori gene, ice $A$, that is associated with clinical outcome. Proc Assoc Am Physicians 110: 531-544, 1998.

36. Mukhopadhyay AK, Kersulyte D, Jeong JY, et al: Distinctiveness of genotypes of Helicobacter pylori in Calcutta, India. J Bacteriol 182: 3219-3227, 2000

37. Clayton CL, Kleanthous H, Coates PJ, Morgan DD and Tabaqchali S: Sensitive detection of Helicobacter pylori by using polymerase chain reaction. J Clin Microbiol 30: 192-200, 1992.

38. Tummuru MK, Cover TL and Blaser MJ: Cloning and expression of a high-molecular-mass major antigen of Helicobacter pylori: evidence of linkage to cytotoxin production. Infect Immun 61: 1799-1809, 1993 